\title{
Selection for Earliness, Yield and Its Components Within Segregated Generation of Broad Bean Hybrids
}

\author{
A. I. A. Abido *, M. A. A. Nassar*, S. A. M. Abd-Allah" and A. F. I. Gohar* \\ "Plant Production Department, Faculty of Agriculture (Saba Basha), Alex. University \\ ${ }^{* *}$ Horticulture Research Institute, Agriculture Research Center, Egypt
}

\begin{abstract}
The present study was carried out during the three successive winter seasons of 2016/2017, 2017/2018 and 2018/2019 in experimental farm of Sabahya, Horticulture Research Station, Alexandria Governorate, Egypt. Selection with self-pollination was conducted for space two isolation of broad bean, produced from cross (P1: Reina mora $\times$ P2: Giza planka) and cross (P2: Giza planka $\times$ P1: Reina mora). Two methods of selection were used, namely mass selection and individual selection of some important characteristics associated with early yield and high productivity of the crop. In the third season (winter season of 2018/2019), the parents and their selected plants from cross first and second selected generation either mass or individual selection were evaluated. To measure the amount of progress in yield and its components and early yield traits of broad bean for two cycles in both selection methods, in addition to a comparison between the progress in using the mass and individual selection and documenting the difference between progress using both methods
\end{abstract}

The obtained results are summarized as follows:

There were significant differences between all strains in all traits under study. There was superiority of the second selected generation and the check cultivar over the original population. There was a remarkable superiority of the strains resulting from the mass selection over the strains produced from the individual selection, as the most of the strains achieving the highest values were within the mass selection strains, but from the reality of the standard deviation values $( \pm S D)$, in general for each selection generation, it was in the interest of the second individual selection generation strains which produced superior strains overall selection generation, indicating that the individual selection is more effective in increasing homogeneity with line. Regarding phenotypic and genotypic coefficient of variance range between them were close in the most traits, these values were in agreement with heritability estimates which being the highest in the same traits. Inbreeding depression were occur in some flowering traits, however, their were good direction for decreasing in is trait and a big role in yielding improvements.

Regarding genetic advance from selection, the total fresh yield followed by total dry yield, achieving the highest values compared to the remaining of the traits. Values of genetic advance as percentage of mean were higher in the first cycle of mass selection than the second one in the most of the characters. This indicates that the genetic advance as percentage of mean, decreased by increasing in selected generation.

Key words: Broad bean, phenotypic variance, genotypic variance, heritability, geneticadvance

\section{INTRODUCTION}

In broad bean, the improvement of yield is a major objective of the most breeding programs. The success of a self-pollinated plant breeding program depends on the choice of genotypes capable of producing progeny with desired trait combinations. Yield in broad bean, similar to the other crops, is a complex trait and constitute by many of physiological and morphological traits that correlated each other. Plant height, pods/plant, number of stems, biological yield, harvest index, 100-seed weight and days to flowering and maturity are very important traits in broad bean improvement for increasing seed yield due to direct and indirect correlation with total yield Loss and Siddique (1997). 
Information on the correlation and linkage among different traits is of primary importance in the field of crop improvement. Correlation relationships can be used to increase breeding efficiency by allowing earlier selection and reducing plant population size during selection, Staub (1999). In statistics, path analysis used to describe the direct and indirect dependencies among a set of variables. Krishna et al. (2007) showed that path coefficient analysis helps in partitioning the correlation coefficient into direct and indirect effect of various traits on yield. It also permits a critical examination of specific forces acting to produce a given correlation and measures the relative importance of each factor.

Traits like days from sowing to first flower and pod appears, number of nodes from sowing to first flower and pod appear, height of the first flower and pod appear have a great effect on early yield on faba bean, and selection for these traits may be effective on early yield improvements, Helaly (2010). The analytical data of broad bean seeds contains a high nutritional value and rich in proteins, carbohydrates, lipids, saturated fatty acids (palmitic acid, stearic acid), unsaturated fatty acids (myristic, pentadecanoic, arachidic, behenic acids, oleic acid, linileic acid, linolenic), vitamins (folic acid, niacin, vitamin c) and micro and macro nutrients according to Vioque et al. (2012). Broad bean a self-pollinated plant with partial cross-pollinated ranging from $20-80 \%$, is a diploid plant with a relatively few number of large chromosomes $(2 n=2 x=12)$, Basheer et al. (2013).

Broad bean (Vicia faba L.) is considered one of the most important winter season seed legume crops which can be grown as multi-purpose crop in areas with short growing season. Many regions of the world are interested in growing broad bean, due to its high nutritional value, important medicinal effect, and biological fixation of nitrogen. Also there were diverse ecosystems benefits are expected from integrating faba bean in cropping systems Fatemeh et al. (2019).

The current investigation was aimed to;

- Determine improvement in yield and its components after two cycles of selection (individual and mass) in segregated generations of broad bean crosses.

- Estimate some genetic parameter i.e. genetic advance (GA), genetic advance as percentage of mean (GAM), heritability in broad sense, genotypic and phenotypic coefficient of variance (GCV, PCV), correlation and path analysis coefficient.

- Comparing the performances of the selected genotypes under the two selection types to determent the best selection type for achieving the highest improvement. 


\section{MATERIALS AND METHODS}

The present investigation was carried out during three successive winter seasons of years 2016/2017, 2017/2018 and 2018/2019 at Faculty of Agriculture (Saba Basha), Alexandria University. The experimental site was the experimental field of Sabahya Horticulture Research Station, Alex, Egypt to evaluate yield and its components for broad bean after two cycles of selection (individual and mass), as well as, estimate some genetic parameters i.e. genetic advance, heritability, genotypic and phenotypic coefficient of variance. Plant materials started by two segregated generations of broad bean crosses which were obtained by Abd-Alla and Tolba (2009) and their parents. The two parents, one Spanish cultivar named Reina mora (P1) and local cultivar named Giza planka ( P2 ), two segregation generations of the following crosses; (P1×P2), (P2 $\times \mathrm{P} 1)$. There for, the plant material gaited by four broad bean populations as follow:

1- Reina mora variety (Spanish cultivar) (P1)

2- Giza planka (local cultivar)(P2)

3- Line isolated from cross (Reina mora× Giza planka)

4- Line isolated from cross (Giza planka× Reina mora)

\section{Field Evaluation and Selection procedure}

In November 2016 plant breeding program was beginning by sowing 2 isolation produced from 2 crosses to practiced two methods selection (mass and individual selection) and evaluation its effects after two selection generation. By the end of selections breeding program, the genetic material of were 21 populations as follow 4 started populations, 4 population from mass selection, 8 population from individual selection in addition check cultivar Cleopatra.

Seeds of the 2 parental cultivars and two segregated generations of previous crosses (4 population) were sown on November $11^{\text {th }}$ during 2016/2017, 2017/2018 and 2018/2019 winter seasons. The 4 population's entries were, randomly, distributed on a randomized complete blocks design with 3 replicates. The seeds were sown in hills spaced $40 \mathrm{~cm}$. apart at the rate of 1 seed/hill. The other normal agricultural practices for broad bean production, i.e., irrigation, fertilization, weeds and pests control were practiced as recommended. In the district for commercial bean production.

Experimental plots were in autumn season of 2018/2019, 2 parents, 2 isolated lines, first mass selection generation ( 2 strains), second mass selection generation (2 strains), first individual selection generation (6 strains) and second individual selection generation ( 6 strains) and the check cultivar sown by $1 \mathrm{seed} / \mathrm{hill}$ in randomized complete block design with three replicates. Each replicate contained 50 rows, (1 row for each population). Each row was $4 \mathrm{~m}$ long and $80 \mathrm{~cm}$ wide, width $40 \mathrm{~cm}$.

Normal agricultural practices used for broad bean production during the three growing season of the study. Data were recorded using guarded / row in all generation as follows:- 


\section{Recorded measurements:-}

Data were recorded using 5 plants / row in all generation as follows:-

1- Flowering measurements:-

Flowering date (days from planting to first flower appear), height of the first flowering node $(\mathrm{cm})$ and number of nodes for first flower appear

2- Fruiting measurements:-

Fruiting (days from planting to first pod holding), height of the first fruiting node $(\mathrm{cm})$ and number of nodes for first pod holding

3- Yield component:-

Number of pods / plant, total fresh yield / plant (g), total dry yield / plant (g) and number of seeds / pod

\section{Selection criteria:}

Flowering days - number of nodes for first flower appear - fruiting (days from planting to first pod appear) -number of nodes for first pod holding number of pods / plant - total fresh yield / plant (g) - total dry yield / plant (g) number of seeds / pod.

\section{Statistical procedures:}

1. Analysis of variance:

Analysis of variance for individual character was done on the basis of the mean values as suggested by Snedecor and Cochran (1980). The model of analysis of variance adopted is given below in Table (1).

Table (1). Analyses of variance

\begin{tabular}{lcccc}
\hline \multicolumn{1}{c}{ S.O.V. } & D.F. & S.S. & M.S. & E.M.S. \\
\hline Blocks & $(r-1)$ & SSB & MSB & $\sigma^{2} e+g \sigma^{2} B$ \\
Genotypes & $(g-1)$ & SSG & MSG & $\sigma^{2} e+b \sigma^{2} g$ \\
$\begin{array}{l}\text { Error } \\
\text { Total }\end{array}$ & $(r-1)(g-1)$ & SSE & MSE & $\sigma^{2} e$ \\
Where $r=$ Number of replicate, $g=$ Number of genotypes & & \\
\hline
\end{tabular}

2. Components of variance:

Genotypic and phenotypic variances were computed from ANOVA Table based on the expected mean sum of squares as follows:

$\begin{array}{ll}\text { (Phenotypic varians) } & V P H=\sqrt{\sigma_{B}^{2}+\sigma_{G}^{2}+\sigma_{E}^{2}} \\ \text { (Genotypic varians) } & V G=\sqrt{\sigma_{G}^{2}}\end{array}$

Where, g: genotypes, B: blocks and E: environment

3. Coefficient of variation:

Genotypic $\left(\sigma^{2} \mathrm{~g}\right)$ and phenotypic $\left(\sigma^{2} \mathrm{ph}\right)$ variance were computed according to Burton (1952). 
Genotypic coefficient of variance $(G C V)=\frac{\sqrt{\sigma_{g}^{2}}}{\bar{x}} \times 100$

Phenotypic coefficient of variance $(P C V)=\frac{\sqrt{\sigma_{p h}^{2}}}{\bar{x}} \times 100$ Where,

$\bar{x}=$ General mean of the trait

\section{Heritability $\left(h^{2} b \%\right)$ :}

Broad sense heritability values were estimated for all studied traits as the ratio of genotypic variance $\left(\sigma^{2} \mathrm{~g}\right)$ to the phenotypic variance $\left(\sigma^{2} \mathrm{ph}\right)$ and was expressed in percentage, Hanson et al. (1956).

( heritability in broad sense) $H_{b s}^{2}=\frac{\sigma_{g}^{2}}{\sigma_{p h}^{2}} \times 100$

5. Genetic advance $\left(G_{A}\right)$ :

$\left(G_{A}\right)$ was computed according to the formula given by Johanson et al. (1955).

$$
G_{A}=i \sqrt{\sigma_{p h}^{2}} H_{b s}^{2}
$$

Where, $H_{b s}^{2}=$ Broad sense heritability. $\quad \sigma_{p h}^{2}=$ Phenotypic standard deviation.

$\mathrm{i}=$ Selection differential 1.76 at 10 selection intensity.

6. Genetic advance as percentage of mean (GAM) and realized gain (RG) \%

(GAM) were calculated as illustrated by Falconer (1989). Using the following formulas:

$$
\begin{aligned}
& \mathrm{GAM}=\left(\mathrm{G}_{\mathrm{A}} \sqrt{\bar{x}}\right) \times 10 \\
& \text { Where, } \mathrm{G}_{\mathrm{A}}=\text { Genetic advance } \quad \bar{x}=\text { General mean of the trait. } \\
& \mathrm{RG} \% \mathrm{C} 1 \text { and original population }=\frac{C 1-C 0}{C 0} \times 100 \\
& \mathrm{RG} \% \mathrm{C} 1 \text { and check variety }=\frac{C 1-\text { Check variety }}{\text { Check variety }} \times 100 \\
& \mathrm{RG} \% \mathrm{C} 2 \text { and original population }=\frac{C 2-C 0}{C 0} \times 100 \\
& \mathrm{RG} \% \mathrm{C} 2 \text { and check variety }=\frac{\text { C2-Check variety }}{\text { Check variety }} \times 100 \\
& \text { Where, } \mathrm{RG}=\text { Realized gain values } \quad \mathrm{C} 0=\text { original population mean } \\
& \mathrm{C} 1=\text { First cycle of selection } \quad \mathrm{C} 2=\text { second cycle of selection }
\end{aligned}
$$

Previous equation were calculated for mass and individual selection lines

7. Inbreeding depression (ID):

(ID) was calculated by formula suggested by Bernstein et al. (1985).

$$
\mathrm{ID}=(\mathrm{S} 0-\mathrm{S} 2) / \mathrm{S} 0) \times 100
$$

Where, $\quad$ S0 $=$ Original population $\quad$ S2 $=$ Second selection generation

\section{RESULTS AND DISCUSSION}

Data presented in Table (2) Show that there were high significant differences among genotypes for all the studied traits. This may be indicated that there were high variations among genotypes under study. Similar results were reported by Alghamdi (2007), Bakheit and Metwali (2011), Abd-ElHaleem and Mohamed (2011) and Sharifi (2014) they stated that the high significant differences between genotypes indicated that the selection may be effective in early generations. 
Data presented in Tables (3) and (4) revealed that vegetative characters (plant height, number of branches, stem thickness), generally increased in first and second cycle of mass selection and individual selection (S1 and S2) compared with original population (SO) this may be due to that these traits affected by selection for high yield trait which correlated with flowering measurements (flowering 'days', first flowering node 'cm' and number of node for first flower 'nods'). Values were decreased in first and second selection cycles, these findings refers to the genotypes become more earliest by inbreeding and selection, these results were in agreement with Karasu and $\mathrm{Oz}$ (2010) their reported that the early yield measurements correlated with several traits and selection for this traits may be led to serve early yielding measurements. Tallest genotype was (P1×P2) in second cycle of mass selection lines $119.7(\mathrm{~cm})$ followed by $(\mathrm{P} 2 \times \mathrm{P} 1)_{\llcorner 2}$ in second cycle of individual selection lines $119.2(\mathrm{~cm})$ with significant differences with most genotypes, In flowering

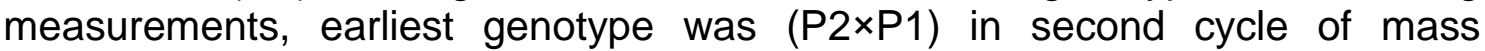
selection lines with 44 (days) for first flower appear, $20.3(\mathrm{~cm})$ for height of the first flowering node and 5.2 number of node for first flower appears.

Regarding fruiting measurements (fruiting 'days', first fruiting node 'cm' and number of nods for first pod) which presented in Table (5) values become smaller in second selection generation (individual and mass selection) than in original population This may be due to relationship between flowering measurements which decreased and fruiting measurements. Yield components traits (number of pods / plant, total fresh yield / plant $(\mathrm{g})$ and total dry yield / plant ( $\mathrm{g}$ ) were in favorable direction by selection, values become greater in first and second selection generation in mass selection and individual selection

In all fruiting measurements, genotype (P2×P1) for the second cycle of mass selection scored the smallest values for fruiting date 58.7 (days), first fruiting node and $23.6(\mathrm{~cm})$ and number of nods for first flower 6.1 (nods) followed by genotype $(\mathrm{P} 1 \times \mathrm{P} 2)_{\mathrm{L} 1}$ in second cycle of individual selection, values were for fruiting date 60.1 (days), first fruiting node and $24.8(\mathrm{~cm})$ and number of nods for first flower 6.7 (nods). But in yield components traits genotypes (P1×P2) L1 for second cycle of individual selection scored highest values for number of pods / plant, 49.2 (pods) followed by (P1×P2) L2 for second cycle of individual selection, 48.3 (pods). Highest genotypes in total fresh yield was (P2×P1) for second cycle of mass selection followed by $(\mathrm{P} 1 \times \mathrm{P} 2)_{\mathrm{L} 1}$ for second cycle of individual selection scored $2127.5 \mathrm{~g}$ (g) and $1676.3 \mathrm{~g}(\mathrm{~g})$, respectively. But

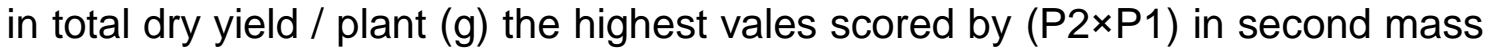
selection cycle with value 549.9 (g) followed by (P2×P1) L1 for first cycle of individual selection with value $455.8(\mathrm{~g})$. concerning pod measurements traits, highest scored values were in genotypes (P2×P1) in second cycle of mass selection for number of seeds / pods 5.5 (seeds), from all previous data it can be noticed that first and second cycles of mass and individual selection lines strong in vegetative characters, earlier, high in total dry and fresh total yield, and have good pod measurements than original populations lines. Regarding check cultivar, there were lines in selection cycles (mass and individual) achieved values bigger than it in most characters.

From slandered deviation data $( \pm S D)$ it can be noticed that values were decreased in second selection generation in mass and individual selection, but 
values in individual selection lines were smaller than in mass selection lines. This finding refer to that the selection serve the homogeneity which led to generation after generation produce pure lines these results were in agreements with Ahmed et al. (2008) and reported that the improvement of production of faba bean can be achievable by purifying of already established cultivars by both mass and individual plant selection programs. Values of variance components, coefficient of variability, heritability in broad and inbreeding depression which presented in Table (5) showed that differences between genotypic variance and phenotypic variance were narrow in traits flowering date, first flowering node, number of node for first flower, fruiting date, first fruiting node, number of node for first pod, number of pods / plant, total fresh yield / plant and total dry yield /plant. These results to reflect on heritability estimates which were in $85.40 \%, 86.83 \%$, $86.31 \%, 87.36 \%, 79.64 \%, 86.44 \%, 76.48 \%, 87.33 \%$, and $86.98 \%$ in the same traits respectively. Low range between genotypic and phenotypic variance was in number of seeds /pod trait with heritability estimate $60.00 \%$. Similar results found by Toker (2004), who found high heritability estimates in broad sense for number of days to flowering. Also Alghamdi (2007) found that the superior estimates were obtained for flowering date, average number of seeds / plant and maturity date.

Regarding inbreeding depression values \%in mass selection, values were negative in all traits except early yielding characters (flowering date, first flowering node, number of node for first flower, fruiting date, first fruiting node and number of node for first pod) these finding indicate to that there were no inbreeding depression in all traits, and the inbreeding depression which found in early yielding traits was praiseworthy results because decreasing in period from sowing to flower or pod appears meaning that the earliness increasing. Same trend of these results were found in individual selection except in traits number of seeds/pod which explained positive values so inbreeding depression occurred on it, these results were disagreements with those found by Bishnoi et al. (2017), they lowest positive inbreeding depression values in traits, values were in average number of seeds/ pod, regarding negative values were relatively low and detected in number of days to $50 \%$ flowering, number of days to maturity. And in agreements with those found by Ahmed et al. (2018) who reported that the selection was effective in improved earliness the original population become more homogenous. 
Table (2). Mean squares for all genotypes after two selection type (mass and individual selection) for flowering, fruiting measurements and yield components among winter season of (2018/2019)

\begin{tabular}{|c|c|c|c|c|c|c|c|c|c|c|c|}
\hline \multirow[b]{2}{*}{ S. O. V. } & \multirow[b]{2}{*}{ D. $F$} & \multicolumn{3}{|c|}{ Flowering measurements } & \multicolumn{3}{|c|}{ Fruiting measurements } & \multicolumn{4}{|c|}{ Yield components } \\
\hline & & $\begin{array}{l}\text { Flowering } \\
\text { days from } \\
\text { planting to } \\
\text { first flower } \\
\text { appear }\end{array}$ & $\begin{array}{c}\text { Height } \\
\text { of the first } \\
\text { flowering } \\
\text { node }\end{array}$ & $\begin{array}{c}\text { Number } \\
\text { of nodes } \\
\text { for first } \\
\text { flower } \\
\text { appear }\end{array}$ & $\begin{array}{c}\text { Fruiting } \\
\text { days } \\
\text { from } \\
\text { planting } \\
\text { to first } \\
\text { pod } \\
\text { holding }\end{array}$ & $\begin{array}{l}\text { Height } \\
\text { of the } \\
\text { first } \\
\text { fruiting } \\
\text { node }\end{array}$ & $\begin{array}{l}\text { Number } \\
\text { of nodes } \\
\text { for first } \\
\text { pod } \\
\text { holding }\end{array}$ & $\begin{array}{c}\text { Number } \\
\text { of } \\
\text { pods } \\
\text { /plant }\end{array}$ & $\begin{array}{l}\text { Total } \\
\text { fresh } \\
\text { yield } \\
\text { /plant }\end{array}$ & $\begin{array}{l}\text { Total } \\
\text { dry } \\
\text { yield } \\
\text { /plant }\end{array}$ & $\begin{array}{c}\text { Number } \\
\text { of } \\
\text { seeds } \\
\text { /pod }\end{array}$ \\
\hline Blocks & 2 & $1.65 \mathrm{~ns}$ & $0.21 \mathrm{~ns}$ & $0.03 n s$ & $6.84 n s$ & $0.11 \mathrm{~ns}$ & $0.01 \mathrm{~ns}$ & $5.11 \mathrm{~ns}$ & 7091.97ns & $792.32 n s$ & $0.04 \mathrm{~ns}$ \\
\hline Genotypes & 20 & $82.64^{\star \star}$ & $28.99^{\star *}$ & $2.23^{* *}$ & $141.7^{\star \star}$ & $34.86^{\star *}$ & $1.85^{\star *}$ & $82.50^{\star *}$ & $255169.31^{\star *}$ & $16912.10^{* *}$ & $0.37^{* *}$ \\
\hline Error & 40 & 4.61 & 1.44 & 0.12 & 6.51 & 2.87 & 0.10 & 7.77 & 7533.80 & 804.21 & 0.13 \\
\hline
\end{tabular}

${ }^{* *}$ Highly significant differences at $1 \%$ level of probability.

Ns: not significant differences 
Table (3). Mean performance and standard deviation values for parents (P1, P2), original populations, first and second selection generation (S1 and S2) of (P1×P2) and (P2×P1) lines over two selection types (mass selection and individual selection) and check cultivar (control) in flowering and fruiting measurements during winter season of $2018 / 2019$

\begin{tabular}{|c|c|c|c|c|c|c|c|c|c|c|c|c|c|}
\hline \multirow{3}{*}{\multicolumn{2}{|c|}{ Genotypes }} & \multicolumn{6}{|c|}{ Flowering measurements } & \multicolumn{6}{|c|}{ Fruiting measurements } \\
\hline & & \multicolumn{2}{|c|}{$\begin{array}{c}\begin{array}{c}\text { Flowering } \\
\text { (days) }\end{array} \\
\end{array}$} & \multicolumn{2}{|c|}{$\begin{array}{c}\text { First flowering } \\
\text { node }(\mathrm{cm})\end{array}$} & \multicolumn{2}{|c|}{$\begin{array}{c}\text { Number of node } \\
\text { for first flower }\end{array}$} & \multicolumn{2}{|c|}{$\begin{array}{c}\begin{array}{c}\text { Fruiting } \\
\text { (days) }\end{array} \\
\end{array}$} & \multicolumn{2}{|c|}{$\begin{array}{c}\text { First fruiting } \\
\text { node }(\mathrm{cm})\end{array}$} & \multicolumn{2}{|c|}{$\begin{array}{c}\begin{array}{c}\text { N. of nodes for } \\
\text { first pod }\end{array} \\
\end{array}$} \\
\hline & & Mean & IS. D & Mean & $\pm S$. D & Mean & \pm S. D & Mean & $\pm S$. D & Mean & \pm S. D & Mean & $\pm S$. D \\
\hline \multirow{2}{*}{ Parents } & \multirow{2}{*}{$\begin{array}{l}1 \text { (Reina mora) } \\
\text { P 2(Giza planka) }\end{array}$} & 56.7 cde & 0.59 & 27.3def & 0.20 & $7.5 \mathrm{cde}$ & 0.09 & $72.7 \mathrm{~cd}$ & 0.69 & $31.7 \mathrm{bcd}$ & 0.23 & $8.2 \mathrm{~cd}$ & 0.10 \\
\hline & & $58.3 \mathrm{bcd}$ & 0.66 & $27.6 \mathrm{cde}$ & 0.37 & 7.7bcde & 0.10 & $73.7 \mathrm{bc}$ & 0.59 & $32.3 \mathrm{bcd}$ & 0.27 & $8.3 \mathrm{~cd}$ & 0.11 \\
\hline \multirow{2}{*}{$\begin{array}{c}\text { Original population } \\
\text { lines (SO) }\end{array}$} & (P1×P2) & $62.7 a$ & 1.29 & $30.7 a$ & 0.88 & $8.4 a$ & 0.17 & $81.2 \mathrm{a}$ & 1.47 & $35.6 a$ & 0.58 & $9.0 \mathrm{a}$ & 0.21 \\
\hline & (P2×P1) & $62.4 a$ & 1.20 & $30.4 a b$ & 0.77 & $8.2 a b$ & 0.15 & $81.4 a$ & 1.40 & $35.4 a$ & 0.65 & $8.9 a b$ & 0.20 \\
\hline \multirow{2}{*}{$\begin{array}{l}\text { First cycle of mass } \\
\text { selection lines (S1) }\end{array}$} & (P1×P2) & $57.4 \mathrm{bcd}$ & 0.76 & 27.5de & 0.38 & $7.5 \mathrm{cde}$ & 0.13 & $73.9 b c$ & 0.80 & $31.9 \mathrm{bcd}$ & 0.40 & $8.4 \mathrm{bcd}$ & 0.17 \\
\hline & (P2×P1) & 48.4hi & 0.71 & $21.4 \mathrm{ij}$ & 0.41 & $5.9 \mathrm{i}$ & 0.14 & $60.4 f$ & 0.93 & $24.9 \mathrm{~g}$ & 0.41 & $6.8 \mathrm{~g}$ & 0.14 \\
\hline \multirow{6}{*}{$\begin{array}{c}\text { First cycle of } \\
\text { individual selection } \\
\text { lines (S1) }\end{array}$} & $(\mathrm{P} 1 \times P 2)_{\mathrm{L} 1}$ & 54.5def & 0.42 & $25.9 \mathrm{efg}$ & 0.46 & 7.3defg & 0.09 & 70.6cde & 0.84 & $30.2 \mathrm{cde}$ & 0.40 & 8de & 0.10 \\
\hline & $(\mathrm{P} 1 \times \mathrm{P} 2) \mathrm{L} 2$ & $60.9 a b$ & 0.49 & $29.8 a b c$ & 0.49 & $8.1 \mathrm{abc}$ & 0.12 & 78.3ab & 0.53 & $34.6 a b$ & 0.33 & $8.7 a b c$ & 0.09 \\
\hline & $(\mathrm{P} 1 \times \mathrm{P} 2) \mathrm{L3}$ & $58.2 \mathrm{bcd}$ & 0.48 & 27.7cde & 0.23 & 7.6bcde & 0.13 & $73.9 b c$ & 0.53 & $32.3 \mathrm{bcd}$ & 0.33 & 8.3bcd & 0.07 \\
\hline & $(\mathrm{P} 2 \times \mathrm{P} 1)_{\mathrm{L} 1}$ & $58.0 \mathrm{bcd}$ & 0.65 & 27.7cde & 0.33 & $7.6 \mathrm{cde}$ & 0.10 & $73.9 b c$ & 0.66 & $32.1 \mathrm{bcd}$ & 0.29 & $8.2 \mathrm{~cd}$ & 0.07 \\
\hline & $(\mathrm{P} 2 \times \mathrm{P} 1) \mathrm{L} 2$ & 60.0abc & 0.43 & $28.4 \mathrm{bcd}$ & 0.29 & 7.9abcd & 0.06 & $75.3 b c$ & 0.65 & 32.9abc & 0.28 & 8.4abcd & 0.11 \\
\hline & $(\mathrm{P} 2 \times \mathrm{P} 1)_{\mathrm{L} 3}$ & 53.0efg & 0.44 & $25.1 \mathrm{fg}$ & 0.20 & 7.1efg & 0.06 & $69 \mathrm{de}$ & 0.54 & $31.3 \mathrm{bcd}$ & 0.33 & $6.9 \mathrm{~g}$ & 0.08 \\
\hline \multirow{2}{*}{$\begin{array}{l}\text { Second cycle of mass } \\
\text { selection lines (S2) }\end{array}$} & (P1×P2) & 49.5ghi & 0.44 & 22.6hi & 0.21 & 6.3hi & 0.06 & $62.1 f$ & 0.57 & $26.5 \mathrm{fg}$ & 0.24 & $7.1 \mathrm{fg}$ & 0.06 \\
\hline & (P2×P1) & $44.2 \mathrm{j}$ & 0.37 & $20.3 j$ & 0.17 & $5.2 \mathrm{j}$ & 0.05 & $58.7 f$ & 0.57 & $23.6 \mathrm{~g}$ & 0.29 & $6.1 \mathrm{~h}$ & 0.11 \\
\hline \multirow{6}{*}{$\begin{array}{c}\text { Second cycle of } \\
\text { individual selection } \\
\text { lines (S2) }\end{array}$} & $(\mathrm{P} 1 \times \mathrm{P} 2)_{\mathrm{L} 1}$ & $47.1 \mathrm{ij}$ & 0.41 & $21.4 \mathrm{ij}$ & 0.24 & $5.8 \mathrm{i}$ & 0.07 & $60.1 f$ & 0.47 & $24.8 \mathrm{~g}$ & 0.26 & $6.7 \mathrm{~g}$ & 0.07 \\
\hline & $(\mathrm{P} 1 \times \mathrm{P} 2) \mathrm{L} 2$ & $52.1 \mathrm{fgh}$ & 0.44 & 24.3gh & 0.28 & $6.8 \mathrm{gh}$ & 0.08 & $66.6 \mathrm{e}$ & 0.64 & 28.2ef & 0.29 & 7.5ef & 0.09 \\
\hline & $(\mathrm{P} 1 \times \mathrm{P} 2)_{\mathrm{L} 3}$ & 56.3cde & 0.30 & 26.6def & 0.21 & 7.4de & 0.06 & $72.4 \mathrm{~cd}$ & 0.60 & $31.5 \mathrm{bcd}$ & 0.23 & 8.1de & 0.06 \\
\hline & $(\mathrm{P} 2 \times \mathrm{P} 1)_{\mathrm{L} 1}$ & $51.7 f g h$ & 0.38 & $24.2 \mathrm{gh}$ & 0.30 & $6.8 f g h$ & 0.08 & $66.4 \mathrm{e}$ & 0.53 & 28.3ef & 0.28 & 7.6ef & 0.05 \\
\hline & $(\mathrm{P} 2 \times \mathrm{P} 1)_{\mathrm{L} 2}$ & $56.4 \mathrm{cde}$ & 0.47 & 26.8def & 0.29 & 7.4def & 0.05 & $72.6 \mathrm{~cd}$ & 0.57 & $31.4 \mathrm{bcd}$ & 0.24 & 8.1de & 0.07 \\
\hline & (P2×P1) L3 & 48.7hi & 0.45 & $21.6 \mathrm{ij}$ & 0.18 & $6.1 \mathrm{i}$ & 0.05 & $60.8 f$ & 0.34 & 29.2def & 0.30 & 7.9de & 0.07 \\
\hline \multicolumn{2}{|c|}{ Check cultivar(Cleopatra) } & $59.5 a b c$ & 0.95 & $28.4 \mathrm{bcd}$ & 0.24 & $7.7 \mathrm{bcd}$ & 0.11 & $75.3 \mathrm{bc}$ & 1.02 & $32.9 a b c$ & 0.45 & $8.4 a b c d$ & 0.15 \\
\hline \multicolumn{2}{|c|}{ L.S. D 0.05} & 3.54 & - & 1.98 & - & 0.65 & - & 4.20 & - & 2.79 & - & 0.51 & - \\
\hline
\end{tabular}

Means with the same alphabetical letter in the column are not significantly different from each other using Duncan's test at $5 \%$ probability. 
Table (4). Mean performance and standard deviation values for parents (P1, P2), original populations, first and second selection generation (S1 and S2) of (P1×P2) and (P2×P1) lines over two selection types (mass selection and individual selection) and check cultivar (control) in yield components during winter season of $2018 / 2019$

\begin{tabular}{|c|c|c|c|c|c|c|c|c|c|}
\hline \multirow{3}{*}{\multicolumn{2}{|c|}{ Genotypes }} & \multicolumn{8}{|c|}{ Yield components } \\
\hline & & \multicolumn{2}{|c|}{ Number of pods / plant } & \multicolumn{2}{|c|}{ Total fresh yield /plant (g) } & \multicolumn{2}{|c|}{ Total dry yield /plant $(\mathrm{g})$} & \multicolumn{2}{|c|}{ Number of seeds /pod } \\
\hline & & Mean & $\pm S$. D & Mean & $\pm S$. D & Mean & \pm S. D & Mean & $\pm S$. D \\
\hline \multirow{2}{*}{ Parents } & \multirow{2}{*}{$\begin{array}{l}\text { P } 1 \text { (Reina mora) } \\
\text { P 2(Giza planka) }\end{array}$} & 37.3cdef & 0.65 & 1146.3def & 9.86 & 365.4 ef & 2.63 & $5.1 a b c$ & 0.06 \\
\hline & & $39.3 \mathrm{cde}$ & 0.69 & 1124.2ef & 10.57 & $436.7 \mathrm{bcd}$ & 2.20 & $5 . a b c$ & 0.06 \\
\hline \multirow{2}{*}{$\begin{array}{c}\text { Original population lines } \\
\text { (SO) }\end{array}$} & (P1×P2) & 34.6defg & 1.17 & $947.1 \mathrm{~g}$ & 34.01 & 347.9 efg & 11.43 & $4.8 a b c d$ & 0.12 \\
\hline & (P2×P1) & $30.6 \mathrm{~h}$ & 1.05 & $951.5 \mathrm{~g}$ & 26.86 & $311.2 \mathrm{fgh}$ & 7.63 & $4.5 \mathrm{cde}$ & 0.08 \\
\hline \multirow{2}{*}{$\begin{array}{l}\text { First cycle of mass } \\
\text { selection lines (S1) }\end{array}$} & (P1×P2) & 38.2cdef & 0.93 & 1126.3ef & 23.30 & $325.8 \mathrm{fgh}$ & 5.40 & $4.7 \mathrm{bcde}$ & 0.06 \\
\hline & (P2×P1) & $31.6 \mathrm{gh}$ & 0.87 & $1641.6 b$ & 22.68 & $449.5 b c$ & 6.76 & $5.1 \mathrm{abc}$ & 0.06 \\
\hline \multirow{6}{*}{$\begin{array}{l}\text { First cycle of individual } \\
\text { selection lines (S1) }\end{array}$} & $(\mathrm{P} 1 \times \mathrm{P} 2)_{\mathrm{L} 1}$ & $39.5 \mathrm{~cd}$ & 0.38 & 1195.1de & 12.68 & 346.7efg & 3.20 & $4.7 \mathrm{bcde}$ & 0.06 \\
\hline & $(\mathrm{P} 1 \times \mathrm{P} 2) \mathrm{L2}$ & 31.3h & 0.34 & $1000.8 \mathrm{fg}$ & 12.10 & 281.5hi & 3.56 & $4.5 \mathrm{cde}$ & 0.06 \\
\hline & $(\mathrm{P} 1 \times \mathrm{P} 2)_{\mathrm{L} 3}$ & 34.0efgh & 0.31 & 1106.3efg & 14.67 & $321.9 \mathrm{fgh}$ & 1.38 & 4.9abcd & 0.06 \\
\hline & $(\mathrm{P} 2 \times \mathrm{P} 1)_{\mathrm{L} 1}$ & $32.9 \mathrm{fgh}$ & 0.32 & 1102.8efg & 15.85 & $249.0 \mathrm{i}$ & 2.81 & $4.1 \mathrm{e}$ & 0.04 \\
\hline & $(\mathrm{P} 2 \times \mathrm{P} 1) \mathrm{L} 2$ & $31.6 \mathrm{gh}$ & 0.34 & $1074.8 \mathrm{efg}$ & 13.38 & 294.9ghi & 3.45 & 4.3de & 0.05 \\
\hline & $(\mathrm{P} 2 \times \mathrm{P} 1)$ L3 & $36.6 \mathrm{cdef}$ & 0.33 & $1238.5 \mathrm{de}$ & 11.08 & $328.9 \mathrm{fgh}$ & 3.14 & $5 a b c d$ & 0.05 \\
\hline \multirow{2}{*}{$\begin{array}{l}\text { Second cycle of mass } \\
\text { selection lines (S2) }\end{array}$} & (P1×P2) & $45.7 a b$ & 0.35 & $1486.0 c$ & 16.57 & $485.2 b$ & 4.09 & 5.0abcd & 0.03 \\
\hline & (P2×P1) & $40.6 c$ & 0.31 & $2127.5 a$ & 14.11 & $549.9 a$ & 2.61 & $5.3 a b$ & 0.05 \\
\hline \multirow{6}{*}{$\begin{array}{l}\text { Second cycle of } \\
\text { individual selection lines } \\
\text { (S2) }\end{array}$} & $(\mathrm{P} 1 \times \mathrm{P} 2)_{\mathrm{L} 1}$ & $49.2 a$ & 0.27 & $1676.3 b$ & 9.06 & $431.0 \mathrm{~cd}$ & 2.97 & $5.3 a b$ & 0.04 \\
\hline & $(\mathrm{P} 1 \times \mathrm{P} 2)$ L2 & $48.3 a$ & 0.25 & 1122.0ef & 5.90 & 354.9 ef & 1.90 & $5.1 \mathrm{abc}$ & 0.04 \\
\hline & $(\mathrm{P} 1 \times \mathrm{P} 2)_{\mathrm{L} 3}$ & $37.9 \mathrm{cdef}$ & 0.29 & 1154.3def & 9.65 & 395.3de & 3.04 & $5.1 \mathrm{abc}$ & 0.04 \\
\hline & $(\mathrm{P} 2 \times \mathrm{P} 1)_{\mathrm{L} 1}$ & $41.3 b c$ & 0.27 & $1291.4 d$ & 8.48 & $455.8 b c$ & 2.83 & 4.9abcd & 0.05 \\
\hline & $(\mathrm{P} 2 \times \mathrm{P} 1)_{\mathrm{L} 2}$ & $37.5 \mathrm{cdef}$ & 0.22 & 1140.3def & 6.04 & $428.0 \mathrm{~cd}$ & 1.86 & $5.3 a b$ & 0.04 \\
\hline & $(\mathrm{P} 2 \times \mathrm{P} 1)_{\mathrm{L} 3}$ & 38.1cdef & 0.31 & $1581.9 b c$ & 10.77 & $429.0 \mathrm{~cd}$ & 2.24 & $5.5 a$ & 0.04 \\
\hline \multicolumn{2}{|c|}{ Check cultivar(Cleopatra) } & $37.1 \mathrm{cdef}$ & 0.74 & 1076.8efg & 12.72 & $351.2 \mathrm{ef}$ & 2.86 & $5 a b c d$ & 0.06 \\
\hline \multicolumn{2}{|c|}{ L.S. D 0.05} & 4.60 & - & 143.23 & - & 46.79 & - & 0.59 & - \\
\hline
\end{tabular}

Means with the same alphabetical letter in the column are not significantly different from each other using Duncan's test at $5 \%$ probability. 
Table (5). Variance components values $\left(\sigma^{2} \mathrm{G}\right.$ and $\left.\sigma^{2} \mathrm{PH}\right),(\mathrm{GCV}, \mathrm{PCV})$, heritability, and Inbreeding depression (mass and individual selection over mean for 18 traits under studied

\begin{tabular}{|c|c|c|c|c|c|c|c|}
\hline \multirow[t]{2}{*}{ Traits } & \multicolumn{2}{|c|}{ Variance } & \multicolumn{2}{|c|}{$\begin{array}{c}\text { Coefficient } \\
\text { of } \\
\text { variability }\end{array}$} & \multirow[t]{2}{*}{$\mathbf{H}_{\text {bs }} \%$} & \multicolumn{2}{|c|}{$\begin{array}{c}\text { Inbreeding } \\
\text { depression } \\
\%\end{array}$} \\
\hline & $\sigma^{2} G$ & $\sigma^{2} \mathrm{PH}$ & PCV & GCV & & M.S & I.S \\
\hline Flowering date & 25.96 & 30.40 & 10.01 & 9.25 & 85.40 & 18.74 & 14.09 \\
\hline First flowering node & 9.21 & 10.70 & 12.52 & 11.67 & 86.83 & 21.65 & 18.15 \\
\hline Node for first flower & 0.71 & 0.85 & 12.58 & 11.70 & 86.31 & 23.07 & 16.58 \\
\hline Fruiting date & 45.00 & 51.52 & 10.18 & 9.52 & 87.36 & 18.40 & 16.10 \\
\hline First fruiting node & 10.67 & 13.40 & 11.96 & 10.67 & 79.64 & 21.94 & 15.15 \\
\hline N. of node for first pod & 0.58 & 0.69 & 10.51 & 9.64 & 86.44 & 19.12 & 14.39 \\
\hline N. of pods / plant & 24.90 & 32.56 & 15.09 & 13.20 & 76.48 & -20.75 & -20.75 \\
\hline Total fresh yield / plant & 78646.2 & 90059.3 & 23.95 & 22.38 & 87.33 & -71.38 & -35.40 \\
\hline Total dry yield /plant & 5369.27 & 6172.82 & 20.78 & 19.38 & 86.98 & -32.84 & -8.94 \\
\hline Number of seeds /pod & 0.12 & 0.27 & 9.13 & 7.07 & 60.00 & -8.04 & 0.38 \\
\hline
\end{tabular}

$\bar{\sigma}^{2} \mathrm{G}$ : Genotypic variance, $\sigma^{2} \mathrm{PH}$ : Phenotypic variance, PCV: Phenotypic coefficient of variance,

GCV: Genotypic coefficient of variance, $\mathrm{H}_{\mathrm{bs}}$ : Heritability in broad sense M.S: Mass selection and I .S: Individual selection

It was clearly that the importance of considering both the genetic advance and heritability of traits rather than considering separately in determining how much progress can be made through selection. In this study, high genetic advance accompanied with high to moderate heritability was observed for all traits under study except pod width and number of seeds /pod. Same trend was found by Mesfin et al. (2019) and reported that these traits were highly heritable and selection of high performing genotypes is possible to the improvement of the traits. Regarding genetic advance as percentage of mean (GAM) values were decreased in second selection generation compared with first selection generation except in traits total dry yield / plant and number of seeds/ pod, these results may be indicate to the magnitude of developments decreased by selection cycle and the improvements were high in the first selection generation than later selection generations.

Table (6) showed the realized gain values were positive in all traits except early yield traits and high in magnitude in $\mathrm{C} 2$ of mass selection (original pop. and check variety) and C2 of individual selection (original population and check variety) than $\mathrm{C} 1$ of mass selection (original population and check variety) and $\mathrm{C} 1$ of individual selection (original population and check variety). But the negative realized gain found in early yield traits (number of days from planting to first flower appears, height of the first flowering node, number of node for first flower appears, days from planting to first pod appears, height of the first fruiting node and number of nods for first pod holdings, these results indicating that this traits going to favorable direction because the negative values meaning decreasing in period from sowing and yielding traits, and increasing in this traits refer to increasing in early yield traits similar results found by Kalia et al. (2003) and Kumar and Kaushik (2017) and they reported that the selection may be effective in early yielding traits more than any other traits. 
Table (6). Genetic advance $\left(G_{A}\right)$, genetic advance as percentage of mean (GAM) for cycle 1 (C1) and cycle 2 (C2) in mass selection and individual selection methods and realized gain \% for cycle 1 (C1) and cycle 2 (C2) in mass selection and individual selection methods compared with original population and check cultivar over mean of flowering, fruiting measurements and yield components for all lines

\begin{tabular}{|c|c|c|c|c|c|c|c|c|c|c|}
\hline & \multicolumn{3}{|c|}{ Flowering measurements } & \multicolumn{3}{|c|}{ Fruiting measurements } & \multicolumn{4}{|c|}{ Yield components } \\
\hline & $\begin{array}{c}\text { Flowering } \\
\text { days from } \\
\text { planting } \\
\text { to first } \\
\text { flower } \\
\text { appear }\end{array}$ & $\begin{array}{l}\text { Height of } \\
\text { the first } \\
\text { flowering } \\
\text { node }\end{array}$ & $\begin{array}{c}\text { Number } \\
\text { of nodes } \\
\text { for first } \\
\text { flower } \\
\text { appear }\end{array}$ & $\begin{array}{c}\text { Fruiting } \\
\text { days from } \\
\text { planting to } \\
\text { first pod } \\
\text { holding }\end{array}$ & $\begin{array}{c}\text { Height } \\
\text { of the } \\
\text { first fruiting } \\
\text { node }\end{array}$ & $\begin{array}{l}\text { Number of } \\
\text { nodes } \\
\text { for first } \\
\text { pod } \\
\text { holding }\end{array}$ & $\begin{array}{c}\text { Number of } \\
\text { pods } \\
\text { / plant }\end{array}$ & $\begin{array}{l}\text { Total } \\
\text { fresh } \\
\text { yield / } \\
\text { plant }\end{array}$ & $\begin{array}{c}\text { Total dry } \\
\text { yield } \\
\text { /plant }\end{array}$ & $\begin{array}{c}\text { Number } \\
\text { of seeds } \\
\text { /pod }\end{array}$ \\
\hline $\mathrm{G}_{\mathrm{A}}$ & 8.29 & 4.98 & 1.37 & 11.04 & 5.13 & 1.24 & 7.68 & 484.11 & 120.28 & 0.31 \\
\hline GAM in $\mathrm{C} 1$ of mass selection & 16.92 & 22.63 & 22.49 & 18.02 & 19.93 & 17.81 & 19.84 & 30.96 & 25.73 & 6.19 \\
\hline GAM in $\mathrm{C} 2$ of mass selection & 16.30 & 20.78 & 21.43 & 16.64 & 18.51 & 17.16 & 19.47 & 29.76 & 27.47 & 6.24 \\
\hline GAM in $\mathrm{C} 1$ of individual selection & 14.85 & 18.71 & 18.57 & 15.37 & 16.54 & 15.31 & 20.77 & 41.66 & 33.37 & 6.06 \\
\hline GAM in $\mathrm{C} 2$ of individual selection & 15.42 & 19.89 & 19.77 & 16.18 & 17.02 & 16.21 & 19.47 & 37.66 & 33.50 & 6.77 \\
\hline \multicolumn{11}{|l|}{ Realized gain percentages \% } \\
\hline C1 of mass selection (original pop.) & -21.71 & -28.06 & -26.68 & -24.65 & -27.52 & -22.05 & 18.50 & 64.74 & 41.81 & 8.93 \\
\hline C1 of mass selection (check var.) & -17.68 & -22.54 & -21.35 & -18.60 & -21.90 & -17.30 & 4.42 & 45.23 & 33.08 & 1.67 \\
\hline $\mathrm{C} 2$ of mass selection (original pop.) & -18.74 & -21.65 & -23.07 & -18.40 & -21.94 & -19.12 & 20.75 & 71.38 & 32.85 & 8.04 \\
\hline $\mathrm{C} 2$ of mass selection (check var.) & -14.57 & -15.64 & -17.49 & -11.85 & -15.88 & -14.20 & 6.39 & 51.08 & 24.68 & 0.83 \\
\hline C1 of individual selection (original pop.) & -10.78 & -12.99 & -11.23 & -11.65 & -12.66 & -9.31 & 13.21 & 22.42 & 9.37 & 11.31 \\
\hline C1 of individual selection (check var.) & -6.19 & -6.31 & -4.78 & -4.55 & -5.88 & -3.79 & -0.24 & 7.92 & 2.64 & 3.89 \\
\hline C2 of individual selection (original pop.) & -14.09 & -18.15 & -16.58 & -16.10 & -15.15 & -14.39 & 20.75 & 35.40 & 8.94 & -0.38 \\
\hline C2 of individual selection (check var.) & -9.67 & -11.87 & -10.53 & -9.36 & -8.56 & -9.18 & 6.40 & 19.37 & 2.23 & -7.02 \\
\hline
\end{tabular}




\section{REFERENCES}

Abd- Allah, S. A. M. and M. H. Tolba (2009). Genetic studies on growth, earliness yield and its components, and seed quality in broad bean ( Vicia faba L.). 1. J. Agric. Sci. Mansoura Univ., Egypt .34(4):3349-3366

Abd-El-Haleem, S. H. M. and G. I. Mohamed (2011). Pedigree selection in two segregating of faba bean (Vicia faba, L.) II- yield and its components traits. World J. Agric. Sci., 7: 792-799.

Ahmed, A. A., M. A. Bakheit, M. A. Sayed, R. E. Mahdy and S. S. Abo Elwafa (2018). Pedigree selection to improve the seed yield in two segregating populations of faba bean (Vicia faba L.)Assiut J. Agric. Sci., (49) No. (2): (15-37).

Ahmed, M. S. H., S. H. M. Abd-El-Haleem, M. A. Bakheit and S. M. S. Mohamed (2008). Comparison of three selection methods for yield and components of three faba bean (Vicia faba L.) Crosses. World J. of Agric. Sci., 4(5): pp.635-639.

Alghamdi, S. S. (2007). Genetic behavior of some selected faba bean genotypes. African Crop Science Conference Proceedings. 8: 709-714.

Bakheit, M. A. and E. M. Metwali (2011). Pedigree selection for seed yield and number of pods per main stem in two segregating populations of faba bean (Vicia faba L.). World App. Sci. J, 15:1246-1252.

Basheer, S. R., M. Shtaya, M. Awad, J. Abdallah and Y. Hamdan (2013). Genetic diversity of Palestine landraces of faba bean (Vicia faba) based on RAPD markers. Genetics and Molecular Research 12 (3): 3314-3323; DOI: $10.4238 / 3.8$

Bernstein, H., H. C. Byerly, F. A. Hopf and R. E. Michod (1985). "Genetic damage, mutation and the evolution of sex science. 229 (4719): 12771281.

Bishnoi, S. K., J. S. Hooda, and P. Sharma (2017). Heterotic responses in yield component traits in faba bean (Vicia faba L.) Forage Res. 41(3): 152-159.

Burton, G.W. (1952). Quantitative inheritance in grass. In proceeding of the six the international grassland congress .Pennsylvania, U.S.A: 217-283.

Falconer, D.S. (1989). Introduction to quantitative genetics third edition, Longman, New York, U.S.A.

Fatemeh, E., M. Hashemi, A. V. Barker, O. R. Zandvakili and X. Liu (2019). Agronomy nutritional value and medicinal application of faba bean ( Vicia faba L.). Hort. PI. J., 5 (4): 170-182.

Hanson, C. H., D. S. Robinson and R. E. Comestock (1956). Biometrical studies of yield in segregating populations of Korean Lespedezas. Agro. J., 48: 268-272.

Helaly, A. A. (2010). Improvement some important characters of broad bean (Vicia faba, L.), through individual plant-and mass-selection methods. MSc. Thesis, Faculty of Agric. Alex. Univ.

Johanson, H. W., H. F. Robinson and R. E. Comstock (1955). Estimates of genetic and environmental variability in soybean. Agro. J. 47: 314-318. 
Kalia, P., S. Sood and Y. Singh (2003). Genetic variability in faba bean for pod yield 8r, its contributing traits. Ind. J Genet 86 PB. 63 : 261-262.

Karasu, A. and M. Oz (2010). A study on coefficient analysis and association between agronomical characters in dry bean (Phaseolus vulgaris L.). Bulgar. J. Agric. Sci. 16: 203-211.

Krishna, R. A. N., A. D. Munshi., T. K. Behera and A. K. Sureja (2007). Correlation and path analysis for yield and biochemical characters in Snake melon SABRO. J. of Breeding and Genetics., 39(1):65-72.

Kumar, P. and P. Kaushik (2017). Genetic variability, heritability and genetic advance for seed yield and other agro-morphological traits in faba bean (Vicia faba L.) genotypes of different origin. Trends in Biosciences 10(4): 1246-1248.

Loss, S. P., K. H. M. Siddique (1997). Adaptation of faba bean (Vicia faba L.) to dryland Mediterranean-type environments. I. Seed yield and yield components. Field Crops Research. 52: 17-28; DOI: 10.1016/S03784290(96)03455-7

Mesfin, T., W. Mohammed and M. Jarso (2019). Genetic variability on seed yield and related agronomic traits of faba bean (Vicia faba L.) genotypes under soil acidity stress in the central highlands of ethiopia. Chemical and Bimolecular Engineering J. 4(4): 52-58

Sendecor, G.H and W.C. Cochran (1980). Statistical methods seventh edition. lowa Stat. Univ. Press. Ames.

Sharifi, P. (2014). Correlation and path coefficient analysis of yield and yield component in some of broad bean (Vicia faba L.) genotypes. Genetika, 46(3): 905-914.

Staub, J. E. (1999). Inheritance and linkage relationships of melon (Cucumis Melo, L.) isozymes. J. Amer. Soc. Hort. Sci., 123:264-272.

Toker, C. (2004). Estimates of broad-sense heritability for seed yield and yield criteria in faba bean (Vicia faba L.). Heredities. 140: 222-225; DOI: 10.1111/j.1601-5223.2004.01780

Vioque, J., M. Alaiz and C. J. Girón (2012). Nutritional and functional properties of ( Vicia faba L.) protein isolates and related fractions. Food Chemistry 132(1): 67-72 


\section{الملخص العربي}

\section{الانتخاب للتبكير والمحصول ومكوناته داخل الأجيال الانعزالية من هجن الفول}

الرومى (الرمان

على إبراهيم على عبيدو*, محمد أحمد عبد الجواد نصار *, سامح عبدالمنعم محمد عبد الله** وعادل فهمى إبراهيم جوهر"

"قسم الانتاج النباتى - كلية الزراعة سابا باشأ- جامعة الاسكندرية

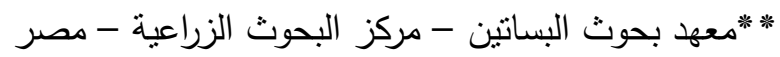

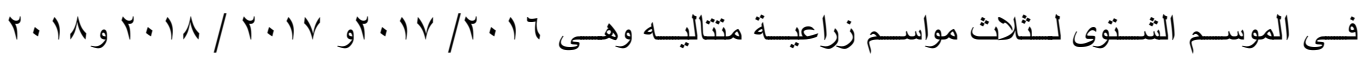

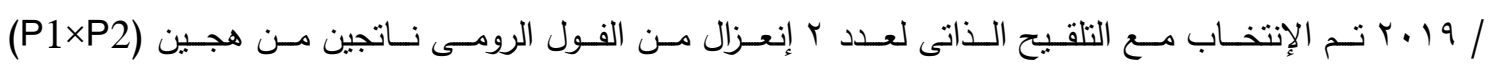

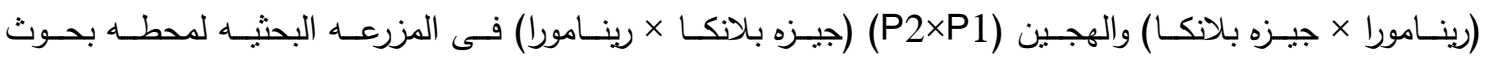

البساتين بالصبحيه وكلية الزراعة سابا باشا جامعة اللإسكندرية.

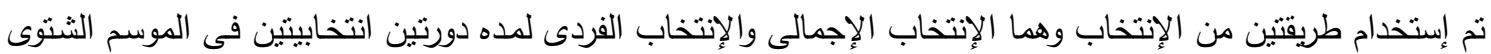

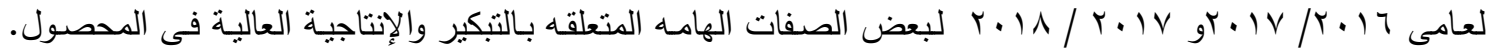

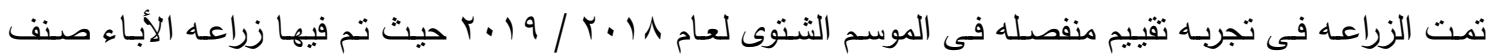
رينامورا (P1) وصنف جيزه بلانكا (P2) بالأضافه للإنعزالات الناتجه منهم كعشيره أصليه (P1×P2) و (P2×P1)

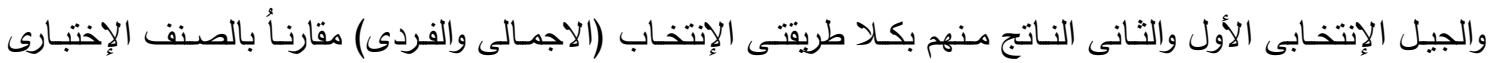
كليوباترا المستتبطة بمركز البحوث الزراعية , لقياس مقدار التحسين الحادث فى بعض صفات الإنى الدحصول والتبكير الهامه فى الفول الرومسي, بالإضـافه للمقارنه بين التقدم الحادث عند إستخدام الإنتخاب الإجمالى والإنتخـاب الفردى وتوثيق الإختلاف فى التقدم الحادث بإستخدام كلا من الطريقتين. وفيمايلي ملخص لألهم النتائج :-

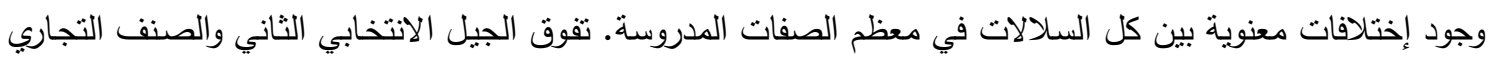

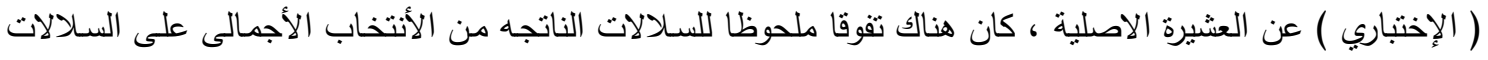

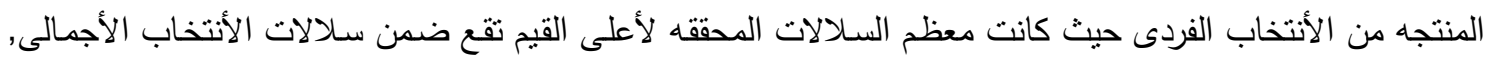

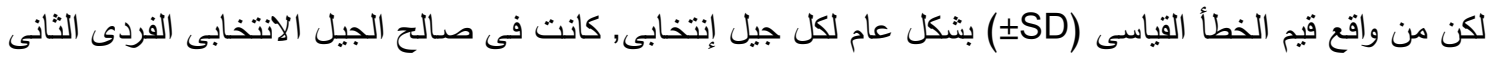

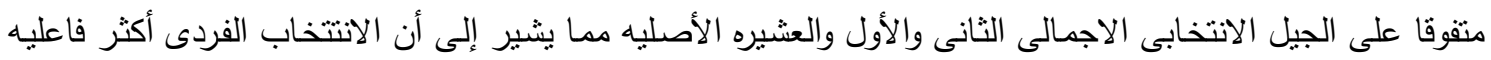

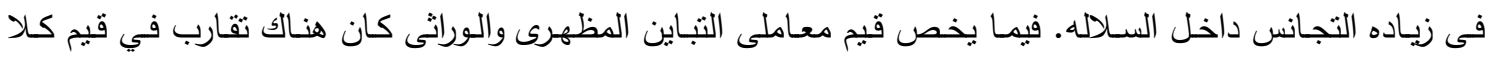

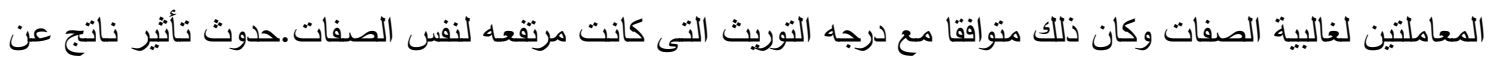

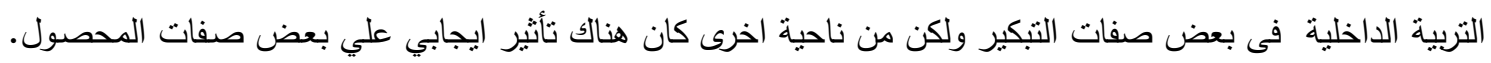

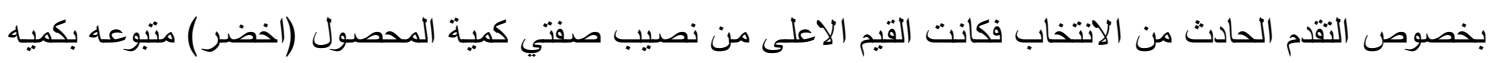
المحصول الكلى(جاف) بالمقارنه بباقي الصفات المدروسة. بالنسبه لقيم التقدم الحادث من الانتخاب كنسبه مئويه من الأن

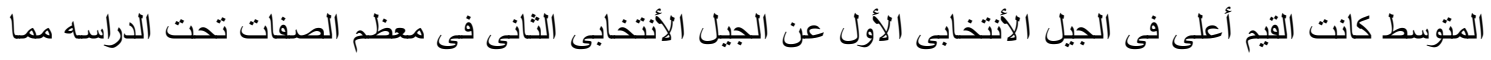
يشير الى ان الاستجابه للانتخاب تقل بزياده عدد الاجيال الانتخابيه. 
